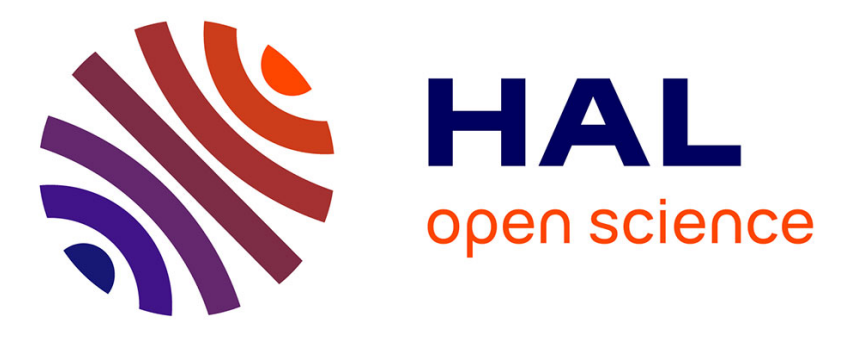

\title{
From inselberg to inselberg: floristic patterns across scales in French Guiana (South America)
}

Corinne Sarthou, Sandrine Pavoine, Jean-Pierre Gasc, Jean-Christophe de Massary, Jean-François Ponge

\section{To cite this version:}

Corinne Sarthou, Sandrine Pavoine, Jean-Pierre Gasc, Jean-Christophe de Massary, Jean-François Ponge. From inselberg to inselberg: floristic patterns across scales in French Guiana (South America). Flora, 2017, 229, pp.147-158. 10.1016/j.flora.2017.02.025 . hal-01494703

\section{HAL Id: hal-01494703 https://hal.science/hal-01494703}

Submitted on 23 Mar 2017

HAL is a multi-disciplinary open access archive for the deposit and dissemination of scientific research documents, whether they are published or not. The documents may come from teaching and research institutions in France or abroad, or from public or private research centers.
L'archive ouverte pluridisciplinaire HAL, est destinée au dépôt et à la diffusion de documents scientifiques de niveau recherche, publiés ou non, émanant des établissements d'enseignement et de recherche français ou étrangers, des laboratoires publics ou privés. 


\section{From inselberg to inselberg: floristic patterns across scales in French}

2 Guiana (South America)

4 Corinne Sarthou ${ }^{1, *}$, Sandrine Pavoine ${ }^{2}$, Jean-Pierre Gasc ${ }^{3}$, Jean-Christophe de Massary ${ }^{4}$, Jean-

5 François Ponge ${ }^{3}$

$6 \quad{ }^{1}$ Muséum National d'Histoire Naturelle, Institut de Systématique, Évolution, Biodiversité,

7 ISYEB UMR 7205 - CNRS, MNHN, UPMC, EPHE, Sorbonne Universités, 57 rue Cuvier, CP

8 39, 75005 Paris, France

$9 \quad{ }^{2}$ Muséum National d'Histoire Naturelle, Département Écologie et Gestion de la Biodiversité, 10 UMR 7204 - CNRS, UPMC, 55-61 rue Buffon, 75005 Paris, France

${ }^{3}$ Muséum National d'Histoire Naturelle, Département Écologie et Gestion de la Biodiversité, UMR 7179 - CNRS, MNHN, 4 avenue du Petit Château, 91800 Brunoy, France

${ }^{4}$ Muséum National d'Histoire Naturelle, Service du Patrimoine Naturel, 36 rue Geoffroy Saint-Hilaire, CP 41, 75005 Paris, France.

${ }^{*}$ Corresponding author

E-mail addresses of the authors:

C. Sarthou: sarthou@mnhn.fr

S. Pavoine: pavoine@mnhn.fr

J.P. Gasc: gasc@mnhn.fr

J.C. de Massary: jean-christophe.demassary@mnhn.fr

J.F. Ponge: ponge@mnhn.fr 


\section{ABSTRACT}

Granitic outcrop vegetation was compared in 22 inselbergs of French Guiana, South America, using RLQ and fourth-corner analyses to identify the main relationships between environmental gradients and plant traits. At the scale of the whole territory the distribution of species and species traits was mostly driven by a spatially-structured gradient embracing regional climate (annual rainfall), forest matrix (canopy openness), and inselberg features (altitude, shape, habitats, summit forest, degree of epiphytism, fire events). Biogeographic, environmental and past historical factors contribute to explain the variation observed at coarse scale and two groups of inselbergs are identified. A first group occupies the southern peneplain in a semi-open forest matrix and exhibits a higher representation of suffrutescent species and climbers, a lower representation of upright shrubs, a lower degree of Guiana Shield endemism, and a higher incidence of human use and autochory. All these features suggest an adaptation to more disturbed environments linked to past climate changes and savannization and to human influences. A second group, characterized by opposite plant traits, occupies the northern part of French Guiana and the far south within a closed forest matrix. Within archipelagos (inselbergs at less than $7 \mathrm{~km}$ distance), C-score and Mantel tests revealed a random co-occurrence of plant species and an increase of floristic dissimilarity with distance without any concomitant change in plant traits, respectively, suggesting that spatially-structured stochastic factors (limitation by dispersal) were the driving force of vegetation change at fine scale.

Keywords: French Guiana; Inselbergs; RLQ and fourth-corner analysis; Endemism; Human use; Savannas 


\section{Introduction}

Inselbergs are dome-shaped rocky outcrops rising above surrounding plains (Bornhardt, 1900). They have been reviewed worldwide for their geological origin and for their biotic diversity by Porembski and Barthlott (2000). They vary in size and height, being sometimes limited to only a few meters (Bremer and Sander, 2000). They can be considered as analogous to functional islands (Prance, 1996) in a general matrix such as deserts, savannas or forests. Whatever their dimensions, the crystalline rocky surface of inselbergs is covered by a peculiar vegetation growing in a shallow soil layer, a general property of rocky outcrop vegetation adding an ecological dimension to the geomorphological definition of "inselbergs" (Gröger and Barthlott, 1996).

In northern South America, inselbergs are especially frequent in French Guiana within the Guiana Shield (Fig.1). They consist of Precambrian granites. Detailed accounts on their geomorphology and geology were provided by some authors (Hurault, 1973; Teixeira et al., 1989; Delor et al., 2003). French Guianan inselbergs are isolated or clustered in groups called archipelagos. They are mainly distributed in all the southern landscapes (Fig. 1): especially large inland plains, plateaus and mountain chains (Guitet et al., 2013). They are covered with discontinuous vegetation forming a type of mosaic locally called "rock savanna”. This vegetation is characterized by numerous scattered herbaceous and shrubby patches separated by bare rock (de Granville, 1978; Sarthou, 1992; Sarthou and Villiers, 1998; Sarthou et al., 2003). The "rock savanna” vegetation is kept in a dynamic state by erosion and fire events (Kounda-Kiki et al., 2008; Sarthou et al., 2009). It undergoes extreme local climate variation during the day-night cycle: high and frequent variations in temperature $\left(18-55^{\circ} \mathrm{C}\right)$ and relative humidity (20-100\%; Sarthou, 1992). Cyanobacteria cover the surface of granitic outcrops (Sarthou et al., 1995) and take part in organic matter production and incipient soil formation (Vaçulik et al., 2004). Soils are generally shallow, acid with low water-holding capacity 
(Sarthou and Grimaldi, 1992). So, inselbergs may be viewed edaphically and climatically as xeric habitats, creating xeric habitat islands in a humid forest matrix.

The influence of past climatic changes in tropical rainforests, especially in South America, has been widely debated (Colinvaux et al. 2000, Willis and Whittaker 2000). The periodic glaciations of the Quaternary corresponded to drier climatic conditions (Hooghiemstra and Hammen 1998). Climatic changes during the last Pleistocene glaciation (between 22000 and 10000 years ago) were characterized by a reduction of rainfall and a drop in temperature by up to $5^{\circ} \mathrm{C}$ compared to the present (Dynesius and Jansson 2000). Consequently, species distributions have been strongly affected (Pennington et al. 2000, Bonaccorso et al. 2006). It has been suggested that these drier and colder periods would have led to the expansion of open vegetation types such as savannas (Hooghiemstra and Hammen 1998). However, climate shifts did not have the same effect over the whole French Guianan territory. During the Holocene, rain forests of the northern part of French Guiana probably remained within the range of more than $2000 \mathrm{~mm}$ annual rainfall (Hooghiemstra and van der Hammen, 1998), and soil carbon isotope studies showed that they did not undergo savannization (Freycon et al., 2010). Forest refuges were located in the north while savannalike vegetation extended in the south (de Granville, 1982; Tardy, 1998). Following de Granville (1982), inselbergs may be interpreted as xeric flora refuges during the present wet period.

The present paper makes the first synthetic and comparative overview of the vascular vegetation spread over granitic outcrops of French Guiana. Our aim is to elucidate the patterns of floristic variation in relation to space, local environment, surrounding environment, plant traits, biogeographic affinities and past history. We also postulate, according to Wiens (1989) that factors acting at fine scale (i.e. within archipelagos) differ from those acting at coarse scale (i.e. over the whole territory of French Guiana). Several hypotheses will be tested. First, 
we hypothesize that at the scale of French Guiana (coarse scale) differences in floristic composition are mainly explained by environmental factors operating directly and indirectly through the selection of adaptive traits (Hypothesis 1). We also hypothesize that past floristic history (biogeographic affinities, climate changes, human settlements) influenced the presentday composition of inselberg vegetation (Hypothesis 2). At last we hypothesize that at fine scale, i.e. within archipelagos, differences in floristic composition result from dispersal limitation by distance rather than from positive and/or negative species interactions (Hypothesis 3).

\section{Materials and methods}

\subsection{Study area}

As part of the Guiana Shield in northern Amazonia, French Guiana (4²13'N, $52^{\circ} 59^{\prime} \mathrm{W}$ ) covers about $85,000 \mathrm{~km}^{2}$ and has a mean altitude of about $140 \mathrm{~m}$ above sea level with few mountainous peaks exceeding $800 \mathrm{~m}$. Its basement, approximately 2.2-1.9 G years in age, corresponds to the oldest and most homogeneous part of the Guiana Shield (Delor et al., 2003). Its climate is equatorial and is characterized by $3000 \mathrm{~mm}$ mean annual rainfall, distributed along a Northeast to Southwest gradient decreasing from about 4000 to $2000 \mathrm{~mm}$ (Fig. 1), with rainfall being concentrated mainly between December and July (Héritier, 2011). Granitic inselbergs were mostly concentrated in southern and eastern parts of the territory (Fig. 1). In the extreme south, groups of elevated dome-shaped inselbergs border the Brazilian Amazonian basin. The peneplain in the southern half part of French Guiana (Fig. 1) is characterised by low elevated and slightly slanting rocky slags in a semi-open forest matrix. The northern half part of French Guiana is covered with a dense rain forest with isolated dome-shaped inselbergs (Gond et al., 2011). 
We studied 22 inselbergs (of which 15 are grouped in 4 archipelagos) scattered over the territory of French Guiana (Fig. 1). We carried out field work to analyse the vegetation of 20 granite outcrops from 1988 to 2011: Nouragues, Trinité A, Mont Chauve, Bakra (A, B), Roche Dachine, Arawa, Wanapi (A, B, C, D, E), Haut Marouini (A, B, C, D, F, G), Mont Saint Marcel, Mitaraka Sud (each letter designates an isolated inselberg). The data set was completed for Trinité B and Virginie through an extraction from the Cayenne Herbarium (CAY) database (available at http://publish.plantnet-project.org/project/caypub): the sampling effort devoted to Trinité B and Virginie by the collectors allowed us to consider these additional records as comprehensive and fully reliable (Appendix A). Geographic coordinates of each site (longitude, latitude) were recorded by a GPS device and are expressed in decimal degrees (coordinate system WGS 84; Appendix A). Sampling effort was adapted to area and environmental heterogeneity of each site, and was included in data analysis in the form of three scores: 1 from one to two days, 2 from 10 to 14 days, and 3 for more than 14 days.

\subsection{Sampling design}

A comprehensive inventory of the vascular flora was undertaken on each rocky outcrop. However, we excluded from the analysis: (1) species growing in the ecotone zone between rock-savanna and the surrounding forested matrix; (2) species growing in summit forests (when present). Consequently, the analysis is restricted to the "rock savanna” facies sensu stricto characterized by vegetation patches on bare rock. Furthermore, we also exclude epiphytic species because the epiphyte layer requires a peculiar sampling protocol. We estimated that the sampling of epiphytes was insufficient.

The final data set comprises 318 plant species (Appendix B). Voucher specimens were deposited in the Cayenne Herbarium (CAY) and were registered in the Cayenne Herbarium database. Plant identification was performed according to Funk et al. (2007). 
150

151

152

153

154

155

156

157

\subsection{Environmental data}

To characterize relevant aspects of the environment we used ten parameters: latitudelongitude, mean annual rainfall according to Héritier (2011), maximum altitude, outcrop area, geographical distance between outcrops, openness of the forest matrix surrounding outcrops, dominant savanna facies, habitats, and occurrence of a summit forest and a cliff (Appendix A).

Mean annual rainfall was coded as 1 from 2200 to 2400 mm, 2 from 2400 to 2600 mm, 3 from 2600 to 2800 mm, 4 from 2800 to 3000 mm, 5 from 3000 to 3200 mm, 6 from 3200 to $3400 \mathrm{~mm}, 7$ from 3400 to $3600 \mathrm{~mm}$, and 8 from 3600 to $3800 \mathrm{~mm}$ and was treated as an ordinal variable.

Maximum altitude was measured during field survey with a GPS device (Appendix A). The area of each outcrop was calculated from aerial photographs and was measured directly in the field for the smallest inselbergs (Appendix A). Geographical distances between inselbergs were calculated using the GIS program Mapinfo ${ }^{\circledR}$ version 9.0.

Canopy openness of the forest matrix surrounding each inselberg was classified as an ordinal variable with three modalities according to data obtained from remote sensing (Gond et al., 2011): dense and regular canopy, mixed canopy and open canopy (Appendix A), coded 1, 2 and 3, respectively. Two facies of savanna (flat-savanna and steep-savanna) were distinguished, their dominance depending on whether the inselberg was flattened or domeshaped, respectively (Appendix A). Each of these facies was coded as 1 or 0 according to its presence or absence in a given inselberg (nominal variable). Note that when both facies were co-dominant (in the case of Roche Dachine) these variables could thus not be considered as redundant and were treated separately. 
The list of habitats available on the rock outcrops was based on Porembski et al. (2000) after refinement from field observations. Twelve types of habitat were retained and treated as nominal variables with two attributes (presence/absence; see Appendix A): cryptogamic vegetation of rock surfaces (habitat 1), wet flush vegetation (habitat 2), vascular epilithic vegetation (habitat 3), vegetation of horizontal or vertical crevices (habitat 4), vegetation of seasonal rock pools in depressions (habitat 5), vegetation on rock debris in depressions (habitat 6), herbaceous vegetation of soil-filled depressions (habitat 7), woody vegetation of soil-filled depressions (habitat 8), ephemeral flush vegetation (habitat 9), monocotyledonous mats on sun-exposed steep rocky slopes (habitat 10), suffrutescent vegetation on sun-exposed rocky slopes (habitat 11) and woody vegetation on sun-exposed rocky slopes (habitat 12). Note that the first habitat type (cryptogamic vegetation $=$ cyanobacteria or lichens in the inselberg context) was present everywhere and thus was not accounted for in the analyses. The number of epiphytic species was measured by an ordinal variable coded as 1 ( $<5$ epiphyte species), 2 (5-10 species), or 3 ( $>10$ species).

\subsection{Plant traits and biogeographic affinities}

To understand the response of outcrop vegetation to environmental variability, we selected seven plant traits and considered biogeographic affinities of each species (Table 1, Appendix B). Growth-form classification was adapted from Ramsay and Oxley (1997). Fruit types were grouped in four major categories according to Lorts et al. (2008). Seed dispersal syndromes were grouped in four categories according to van der Pijl (1982) and Howe and Smallwood (1982). Dispersal mechanisms of species were either recorded in the field or based on fruit and seed morphology. Data were also collected in literature (Roosmalen, 1985). Each plant species was assigned to one or more of these dispersal syndromes, which were treated as distinct dummy variables. 
Considering the high xeric environmental constraints on inselberg vegetation, species presenting a crassulacean acid metabolism (CAM) were identified from literature (Lüttge, 2007; Silvera et al., 2009, 2010; Crayn et al., 2015) and succulent species were also identified (personal observations).

Human use of plant species in the Guianas was documented from Grenand et al. (2004), DeFilipps et al. (2004) and Cadamuro (2000) in order to disclose potential humanmediated effects.

Data concerning the geographic distribution of taxa were mainly obtained from diverse Neotropical floras, especially Steyermark et al. (1995-2005) and Funk et al. (2007), and from the on-line Brazilian Herbarium (available at http://reflora.jbrj.gov.br/jabot/herbarioVirtual/). Biogeographic classes were first specified according to de Granville (1992) and Kelloff and Funk (2004), then were grouped in three categories according to their affinity to the Guiana Shield, the Neotropics or elsewhere (Table 1, Appendix B). A nominal variable describing the degree of Guiana Shield endemism was created by assigning to each group a score varying from 1 to 3.

\subsection{Statistical analyses}

The joint structure of species, species traits and environmental factors at the scale of the whole territory of French Guiana (Hypothesis 1) was analysed by a combination of two methods: RLQ (Legendre et al., 1997) and fourth-corner tests (Dolédec et al., 1996). Both methods are complementary and can be combined in a procedure described by Dray et al. (2014) which allows the graphical representation of species-trait-environment relationships and to test them by a Monte-Carlo simulation method. These calculations were done using the module ade4 package of $\mathrm{R}$ (R Core Team, 2016). 
Three matrices were created for RLQ: a matrix crossing sites (inselbergs) with

environmental variables (matrix R), a matrix crossing sites with species occurrences (matrix L) and a matrix crossing species with species traits (matrix Q). They were simultaneously ordinated, resulting in a factorial hyperspace of reduced dimensions (RLQ factorial axes) in which sites, species, species traits and environmental variables can be simultaneously projected, with permutation procedures to evaluate the significance of their relationships. Taxonomic units, growth forms, fruit types, levels of endemism and carbon metabolic types were considered as nominal variables with 4, 9, 4, 3 and 3 modalities each, respectively. Dispersal types, which are not exclusive, were considered as separate dummy variables. To original spatial variables (longitude as $\mathrm{x}$ and latitude as $\mathrm{y}$ ), which only describe east-west and north-south gradients, respectively, we added polynomial combinations of scaled latitude and longitude $\left(\mathrm{x}^{2}, \mathrm{y}^{2}, \mathrm{x}^{3}, \mathrm{y}^{3}, \mathrm{x}^{2} \mathrm{y}, \mathrm{xy}^{2}\right)$ which could potentially reveal a higher variety of spatial patterns (Borcard et al., 1992). In matrices R and Q, ordinal variables were rank transformed and treated as quantitative. Both matrices were then analysed using Principal Component Analysis (PCA) designed for both nominal and quantitative variables (Hill and Smith, 1976). Fourth corner tests were first used to test the significance of the relationships between each trait modality and each environmental variable. The high number of combinations did not allow finding significant relationships between traits and environment, once significance levels were adjusted for simultaneous comparisons, despite global significance of traitenvironment relationships. Thereby the alternative procedure suggested by Dray et al. (2014) was applied. Cross comparisons between traits and environmental variables were replaced by testing directly the links between RLQ axes and both traits and environmental variables, after adjustment for multiple comparisons (Benjamini and Yekutieli, 2001), using the fourthcorner.rlq function. 
Variance partitioning between space and environment was achieved by the procedure

247 proposed by Borcard et al. (1992), using simple and partial Redundancy Analysis (RDA) with either species or traits as dependent (explained) variables and environmental variables as independent (explanatory) variables. The species matrix was the L matrix used for RLQ. The trait matrix was constructed by assigning to each site (inselberg) the \% contribution of each trait modality, which was calculated as the number of species possessing a given trait modality divided by the number of species recorded in the inselberg (Appendix A). Floristic and environmental data were standardized by reweighting and focusing (mean $=0$, standard deviation =1). Calculations were done with XLSTAT $^{\circledR}$ version 2016.

The influence of past floristic history (Hypothesis 2) was partly tested by the above procedures (RLQ followed by fourth-corner tests). The human use of plant species and their degree of endemism to the Guiana Shield (biogeographic affinity) were considered as traits, which were thus included in the Q matrix and analysed by RLQ and fourth-corner tests. Other factors could not be introduced as variables but a critical examination of a wide corpus of literature allowed discussing these influences in a special chapter.

Fine-scale patterns of floristic change (Hypothesis 3) were studied by comparing species or trait dissimilarity (Jaccard index and Spearman-rank dissimilarity, respectively) with geographic distance for couples of inselbergs belonging to the same archipelago simulation (9999 replicates) was performed within each inselberg group (archipelago) before computing a global correlation coefficient according to a procedure implemented in ade4 (R

267 Core Team, 2016).

Departure from random variation in the co-occurrence of plant species was tested both at coarse-scale (the whole set of inselbergs) and at fine-scale (within archipelagos) using checkerboard C-scores (Stone and Roberts, 1990). This measure of community structure 
271 calculates the number of checkerboard units (specimens in which two taxa are not found together) between all possible taxon pairs in a matrix, and calculates a single score for the entire data set. The C-score is the average for all of the possible pairs in the matrix. This measure is compared with a null distribution of random matrices of the same size. If the observed C-score is larger than the score for the null hypothesis, it suggests significant segregation between taxa, and if the observed C-score is smaller than the score for the null hypothesis, it suggests significant aggregation between taxa. Regression tests were done with XLSTAT $^{\circledR}$ version 2015, and C-scores were calculated using EcoSim Professional ${ }^{\circledR}$.

\section{Results}

Permutation tests (9999 replicates) showed that there was a global link between traits and environment $(\mathrm{P}<0.01)$. The distribution of eigenvalues $(1.485,0.069,0.046,0.029$, and 0.016 for the first five factorial axes) showed an abrupt shift from the first factorial axis (88.4\% of total inertia) to the second one ( $4.1 \%$ of total inertia). Thereby only the first factor (called RLQ1) will be taken into consideration in the following, although two-dimensional plots were thought to be visually more comfortable. Results of RLQ analysis and fourthcorner tests (Hypotheses 1 and 2) were represented by figures 2 to 5 . For the sake of clarity, sites, species, traits and environmental variables were represented as separate bi-plots but it should be noted that their projection was simultaneous.

The projection of sites (Fig. 2) showed a clear separation between two groups of inselbergs, (i) the southern peneplain (Haut Marouini, Wanapi, Arawa) with negative coordinates, and (ii) a group with positive coordinates comprising the far south (Mitaraka, Mont Saint Marcel) and the northern group (Roche Dachine, Monts Bakra, Mont Chauve, Nouragues, Virginie, Trinité). 
For the two groups, dominant families and their species numbers are indicated in

Table 2. The group including northern inselbergs, Mitaraka and Mont Saint-Marcel inselbergs, exhibits a greater number of families and species than the peneplain group (69 families versus 55 families; 265 species versus 149 species). In the first group, the best represented families are Orchidaceae and Bromeliaceae, including numerous epilithic and terrestrial herbs, and Myrtaceae, Clusiaceae and Rubiaceae, including numerous upright shrubs growing in dense thickets. All these families are poorly represented in inselbergs of the peneplain group (Table 2). In the two groups, Poaceae, Cyperaceae, Fabaceae and Melastomataceae families are well represented.

RLQ1 was significantly and positively associated with rainfall, latitude, squared and cubed latitude, inselberg area, presence of a summit forest, of steep slopes, epiphytism (all with $\mathrm{P}<0.01$ ), altitude and presence of habitat 10 corresponding to monocotyledonous mats (both with $\mathrm{P}<0.05$ ). It was significantly and negatively associated with openness of the surrounding forest matrix, longitude, the product of squared latitude with longitude, the presence of flat areas and of habitat 11 corresponding to suffrutescent vegetation (all with $\mathrm{P}<$ 0.01). The gradient depicted by RLQ1 associated spatial and environmental factors, opposing small, low elevated and flattened inselbergs of the southern peneplain to large, dome-shaped, elevated inselbergs of the northern group and of the extreme south along a gradient of increasingly rainy climate and associated ecological features (closed forest matrix, summit forest, bromeliacean mats, and shrub thickets with epiphytes).

Among plant traits, RLQ1 was significantly and positively associated with the highest degree of Guianan endemism $(\mathrm{P}<0.05)$, upright shrubs $(\mathrm{P}<0.01)$, and was significantly and negatively associated with human use, autochory, suffrutescence (all with $\mathrm{P}<0.01$ ) and climbers $(\mathrm{P}<0.05)$. 
The decomposition of the total variance in environmental, spatial and spatially-

structured (shared) variation (Table 3) showed that traits compared to species displayed a higher (x 2) contribution of spatially-structured environment and a lesser contribution of pure space (x 0.74). Both species and traits showed a higher contribution of pure environment than of pure space, the ratio being higher for traits (1.9) than for species (1.5).

At fine scale (Hypothesis 3), Figure 6 showed a discrepancy between species and traits when their dissimilarity was plotted against geographical distances: dissimilarity between inselbergs included within archipelagos increased with distance when species were considered (Mantel correlation coefficient $\mathrm{r}_{\mathrm{M}}=0.53 ; \mathrm{P}=0.019$ ), while the correlation between trait and geographical matrices was feeble $\left(\mathrm{r}_{\mathrm{M}}=0.10\right)$ and not significant $(\mathrm{P}=0.62)$ when traits were considered.

Checkerboard scores (Table 4) showed that plant species co-occurred at random at fine scale (among inselbergs located within the same archipelago) but did not at coarse scale (over the whole set of inselbergs), pointing to stochastic factors explaining changes in floristic composition within archipelagos, while floristic changes between archipelagos are mainly explained by non-stochastic factors.

\section{Discussion}

\subsection{Abiotic parameters and response traits at coarse and fine scale}

RLQ and fourth-corner analyses support our Hypothesis 1 and reflect how at coarse scale, differences in floristic composition are mainly explained by environmental factors operating directly and indirectly through the selection of adaptive traits. Species trait distribution changed according to a composite, spatially-structured gradient, embracing variations in climate (annual rainfall, and associated vegetation features: epiphytism, summit forest, habitats), inselberg shape (flattened versus dome-shaped, low versus high elevation), 
composition of the surrounding forest (semi-open versus closed canopy) and human influences. Among traits, suffrutescence, climbers, and autochory are drought-adaptive traits (Monneveux and Belhassen, 1996; Schnitzer, 2005). These traits are better represented at a lower level of annual rainfall on peneplain inselbergs by Ernestia spp. Spermacoce spp., Dioclea guianensis, Cissus erosa, Omphalea diandra (Fig.3). Conversely, upright shrubs represented by Clusia spp. and Myrcia spp. (Fig. 3), which constitute dense thickets on northern inselbergs (Sarthou et al., 2003; Fonty et al., 2009), and Guianan endemics, adapted to a more rainy climate than Central Amazonian species (Ter Steege et al., 2000), are better represented at a higher level of annual rainfall, showing the importance of climate in the composite gradient depicted by RLQ. A similar situation has been recorded in a study performed on African inselbergs by Parmentier et al. (2005), showing rainfall as the second main driver of floristic heterogeneity at regional scale, after altitude.

Among habitats, annual-perennial herbaceous mats, the dominant vegetation type of inselberg savannas (Porembski et al., 2000) show a southwards shift from epilithic bromeliacean mats (habitat 10) on slopes with flowing water, dominated by Pitcairnia geyskesii (Fig. 3) to grassy suffrutescent meadows (habitat 11) on flat areas with shallow mineral soil, dominated by suffrutescent species such as Stylosanthes guianensis, Chamaecrista desvauxii, Ernestia spp., Unxia camphorata, Sinningia incarnata, Sipanea pratensis, Spermacocce spp. and graminaceous species such as Ischaemum guianense and Axonopus ramosus (Fig. 3). Habitat 11 is reminiscent of the dominant inselberg vegetation of less rainy countries both in the Neotropics (Porembski et al., 1998) and in Africa (Parmentier et al., 2005) which have in common poikilohydric sedges belonging to the genera Trilepis and Afrotrilepis, respectively.

The climate effect, mediated by adaptive traits, does not preclude the existence of other indirect effects of climate, such as those mediated by surrounding cryptogamic 
vegetation (biological crusts), known to affect germination and survival of vascular plants and nutrient availability (Belnap et al., 2001; Sarthou et al., 2009): the lower biomass of cyanobacteria or the replacement of cyanobacteria by lichens along the southwards aridity gradient has probably influenced the floristic composition to some extent.

Climate influences also the structure of the forest matrix (the rain forest) and thus influences regional species pools from which inselberg floras are filtered (Burke, 2002). A noticeable difference in floristic composition (beta diversity) was reported between the forest located in the northern part and the southern part of French Guiana, in relation to geomorphology (Sabatier and Prévost, 1990), and a general pattern may be described at a regional scale (Gond et al., 2011; Guitet et al., 2015). At present, southern forests, with their lower level of annual rainfall, are characterized by their almost open aspect (discontinuous canopy), especially in the southern peneplain where numerous local clearings are found, while northern forests show a continuous canopy typical for rain forests (Gond et al., 2011).

Elevation may also yield contrasting effects on floristic composition. If present and past climate prove to be important factors, local environmental variables (shape, elevation, presence of summit forest) also contribute strongly to explain inselbergs' floristic composition. As evidence, all dome-shaped and elevated inselbergs with summit forest are quite similar in composition even if far in the (drier) south, like St Marcel and Mitaraka, or in the (wetter) north, like Nouragues. We suppose that this local environmental effect which contributes to the observed floristic variation (Table 3) could be related to micro-climate. In fact it has been shown that at mid-elevation water condensation favours fern diversity (Kluge et al. 2006) and a higher biomass and diversity of epiphytes (Gehrig-Downie et al., 2011, 2013). The frequent mists we observed on the most elevated inselbergs (Mitaraka) in the dry season, together with relatively low temperature $\left(19^{\circ} \mathrm{C}\right)$, may explain why inselbergs of the far south, while being in a lower precipitation zone (Fig. 1) share more species and species 
traits with the northern group than with the southern group. Montane species settled during glacial (drier) periods may have survived here under these conditions, making Mitaraka and Saint Marcel important refuges for Pleistocene floras.

At fine scale, C-scores (Table 4) showed that inselbergs of the same archipelago did not display any checkerboard pattern of floristic composition. There was no segregation of species due to competition (Bowker and Maestre, 2012) and/or priority effects (Fukami, 2015), as well as no positive interspecific interactions (López et al., 2016). However, floristic dissimilarity within archipelagos increased with distance, while trait dissimilarity did not change (Fig. 6), supporting our Hypothesis 3 of dispersal limitation by distance in a common environmental context, i.e. when inselbergs share similar environmental conditions and have most probably undergone a common history (Flinn et al., 2010). Parmentier and Hardy (2009) also showed that differences in floristic composition result from dispersal limitation by distance on African inselbergs.

\subsection{Influence of past climate changes and human use}

RLQ and fourth-corner analyses also allowed checking part of our second hypothesis while taking Guiana Shield endemism and human use as proxies for past history.

Endemism is better represented at a higher level of annual rainfall. Past climate changes during the Pleistocene and the Holocene are generally evoked to explain this. These climatic changes have modified the floristic composition of the matrix, the rain forest being replaced by open forests or even savannas, relative elevation being increased by lowering of the sea level, with mountain taxa coming into lowland forest (Hooghiemstra and Hammen 1998, Pennington et al. 2004; Rull, 2005; Pinter et al., 2011). However, in French Guiana, a clear difference appears between northern and southern forests. The northern part revealed a 
high degree of tolerance during Holocene drier climatic periods (Hooghiemstra and van der Hammen, 1998; Tardy, 1998; Freycon et al., 2010) and constituted rain forest refuges which remained genetically isolated (Granville, 1982; Tardy, 1998; Boisselier-Dubayle et al., 2010). This continuous-in-time isolation may be considered as a reason for a high degree of endemism (Vuilleumier, 1970). Our data (Appendix A) showed that inselbergs of the northern part had on average 30.1 $\pm 1.4 \%$ (mean \pm SE) Guianan endemics (Guiana Shield + Guianas + French Guiana) against only $19.7 \pm 0.8 \%$ for the southern group, the Mitaraka group being intermediate with $23.6 \pm 0.4 \%$ endemics.”

In contrast, the southern part displays much disturbance and fire witnesses (Tardy, 1998), suggesting the occurrence of a past savanna-like matrix (and thus numerous exchanges of diaspores) around the numerous inselbergs present today in the peneplain zone. Human use, autochory as characteristic dispersal type, suffrutescence and climbers as characteristic growth types, all these features being associated with the 'negative' side of the gradient, are indicators of disturbance of the environment. Autochory, i.e. the absence of dispersal, does not facilitate avoidance in space but generates an abundant soil seed bank, an adaptive strategy used by plant communities when faced to recurrent destruction and regeneration of the vegetation cover (Valbuena and Trabaud, 2001). Suffrutescence and climbers are also associated to such environments, with a high power of post-disturbance regeneration from subterranean organs (Keeley et al., 2006; Schnitzer, 2005). Among causes of disturbance, in addition to seasonal and inter-annual abrupt changes in climate conditions, human activities probably play a non-negligible role, with concomitant increases in trampling, fire, erosion and deletion of species (Pinter et al., 2011). The low elevated and flattened inselbergs of the peneplain are of easy access and Hurault (1989) indicates a high density of Indian tribes in this southern zone. 
Otherwise, the ancient and long-time occurrence of Indian populations in the peneplain was considered. Convergent data integrate the southern plain of French Guiana within a large continuous savanna zone spreading from the Venezuelan Llanos, including Roraima, Rupununi, Sipaliwini savannas (Fig. 1) to the upper and middle parts of the northern tributaries of the Amazon River during drier periods of the Holocene (Mayle and Power, 2008). This zone also played the role of a corridor for human dispersal (Plew, 2005; Piperno, 2011). In this context, men probably lived in open areas and used slash-and-burn technics only in the nearby forest, exploiting ecotone plant diversity (Plew, 2005). The fact that wild manihot (Manihot esculenta ssp. flabellifolia) found on southern inselbergs displays a striking genetic homogeneity (Duputié et al., 2009) is a probable legacy of ancient human management by fire and cultivation in a savanna-like context. This created repeated contacts between inselbergs and temporary colonization of open space in the plain by wild stems of several cultivated plants. Floristic affinities between rock savannas of the peneplain and savannas also suggest the occurrence of an ancient connection between them. Thus, we evaluate that the peneplain inselbergs share $30 \%$ of species with Sipaliwini savanna (van Donselaar, 1968; Oldenburger et al., 1973).

\section{Conclusion}

Our study provides evidence that regional climate, surrounding forest matrix and inselberg features (altitude, shape, habitats, summit forest, epiphytism, fire events) are associated to shifts in the distribution of species and functional traits and determine floristic patterns on French Guianan inselbergs. The study also improves our understanding on how past climatic changes leading to savannization events in the South and how humans using outcrop plants can affect the species composition of inselbergs in the southern peneplain. The high degree of Guiana Shield endemism of inselbergs located within the northern rainforest, 
467 which were seemingly neither affected by past climatic changes nor by human uses points to

468 the need to protect them.

\section{Acknowledgements}

471 This research paper is the end-product of several projects and was mainly supported by

472 a grant from Feder n¹348 (Contrat Plan Etat Région with Ecofor/Gis Silvolab-Guyane, IRD,

473 MNHN as partners). We are grateful to Jean-Jacques de Granville for his field contribution, 474 help in species identification and fruitful discussions. We also thank two anonymous

475 reviewers for their constructive comments on the manuscript. We acknowledge the curator of 476 the Cayenne Herbarium (CAY), Sophie Gonzalez for providing database information. We

477 also thank G. Cremers, F. Crozier, L. Aliker, P. Gaucher for their assistance in field work. M. 478 Boudrie, T. Deroin, P. Grenand, V. Guérin, P. Héritier, P. Joubert and B. Lefeuvre have also 479 provided interesting data in their respective scientific domains.

Appendix A. Spatial and environmental data

\section{Appendix B. Floristic data}

483 Supplementary data associated with this article can be found, in the online version, at 484 http://dx.doi.org/xxxx.

485 


\section{References}

Belnap, J., Prasse, R., Harper, K.T., 2001. Influence of biological soil crusts on soil environments and vascular plants, in Belnap, J., Lange, O.L. (Eds.), Biological soil crusts: structure, function, and management. Springer, Berlin, pp. 281-300.

Benjamini, Y., Yekutieli, D., 2001. The control of the false discovery rate in multiple testing under dependency. Ann. Statist. 29, 1165-1188.

Boisselier-Dubayle, M.C., Leblois, R., Samadi, S., Lambourdière, J., Sarthou, C., 2010. Genetic structure of the xerophilous bromeliad Pitcairnia geyskesii on inselbergs in French Guiana: a test of the forest refuge hypothesis. Ecography 33, 175-184.

Bonaccorso, E, Koch, I., Townsend Peterson, A., 2006. Pleistocene fragmentation of Amazon species'ranges. Divers. Distrib. 12, 157-164.

Borcard, D., Legendre, P., Drapeau, P., 1992. Partialling out the spatial component of ecological variation. Ecology 73, 1045-1055.

Bornhardt, W., 1900. Zur Oberflächengestaltung und Geologie Deutsch-Ostafrikas. Reimer, Berlin.

Bowker, M.A., Maestre, F.T., 2012. Inferring local competition intensity from patch size distributions: a test using biological soil crusts. Oikos 121, 1914-1922.

Bremer, H., Sander, H., 2000. Inselbergs: geomorphology and geoecology, in Porembski, S., Barthlott, W. (Eds.), Inselbergs: Biotic Diversity of Isolated Rock Outcrops in Tropical and Temperate Regions. Springer, Berlin, pp. 7-35.

Burke, A., 2002. Island-matrix relationships in Nama Karoo inselberg landscapes. I. Do inselbergs provide a refuge for matrix species? Plant Ecol. 160, 79-90.

Cadamuro, L., 2000. Plantes Comestibles de Guyane. Ecocart, Toulouse. 
511 Colinvaux, P.A., de Oliveira, P.E., Bush, M.B., 2000. Amazonian and neotropical plant communities on glacial time-scales: the failure of the aridity and refuge hypotheses. Quaternary Sci. Rev. 19, 141-169.

514

Crayn, D.M., Winter, K., Schulte, K., Smith, J.A.C., 2015. Photosynthetic pathways in Bromeliaceae: phylogenetic and ecological significance of CAM and C3 based on carbon isotope ratios for 1893 species. Bot. J. Linn. Soc. 178, 169-221.

DeFilipps, R.A., Maina, S.L., Crepin, J., 2004. Medicinal Plants of the Guianas (Guyana, Surinam, French Guiana). Smithsonian Institution, Washington. http://botany.si.edu/bdg/medicinal/Medicinal_plants_master.pdf (accessed 11.05.16).

Delor, C., Lahondère, D., Egal, E., Lafon, J.M., Cocherie, A., Guerrot, C., Rossi, P., Truffert, C., Théveniaut, H., Phillips, D., de Avelar, V.G., 2003. Transamazonian Crustal Growth and Reworking as Revealed by the 1:500,000-Scale Geological Map of French Guiana. Bureau de Recherches Géologiques et Minières, Orléans.

Dolédec, S., Chessel, D., ter Braak, C.J.F., Champely, S., 1996. Matching species traits to environmental variables: a new three-table ordination method. Environmental and Ecological Statistics 3, 143-166.

Dray, S., Choler, P., Dolédec, S., Peres-Neto, P.R., Thuiller, W., Pavoine, S., ter Braak, C.J.F., 2014. Combining the fourth-corner and the RLQ methods for assessing trait responses to environmental variation. Ecology 95, 14-21.

Duputié, A., Delêtre, M., de Granville, J.J., McKey, D., 2009. Population genetics of Manihot esculenta ssp. flabellifolia gives insight into past distribution of xeric vegetation in a postulated forest refugium area in northern Amazonia. Mol. Ecol. 18, 2897-2907.

Dynesius, M., Jansson, R, 2000. Evolutionary consequences of changes in species’ geographical distributions driven by Milankovitch climate oscillations. Proc. Nat. Acad. Sci. USA 97, 9115-9120. 
536 Flinn, K.M., Gouhier, T.C., Lechowicz, M.J., Waterway, M.J., 2010. The role of dispersal in

537

538

539

540

541

542

543

544

545

546

547

548

549

550

551

552

553

554

555

556

557

558

559 shaping plant community composition of wetlands within an old-growth forest. J. Ecol. 98, 1292-1299.

Fonty, E., Sarthou, C., Larpin, D., Ponge, J.F., 2009. A 10-year decrease in plant species richness on a neotropical inselberg: detrimental effects of global warming? Global Change Biol. 15, 2360-2374.

Freycon, V., Krencker, M., Schwartz, D., Nasi, R., Bonal, D., 2010. The impact of climate changes during the Holocene on vegetation in northern French Guiana. Quaternary Res. 73, 220-225.

Fukami, T., 2015. Historical contingency in community assembly: integrating niches, species pools, and priority effects. Ann. Rev. Ecol. Evol. Syst. 46, 1-23.

Funk, V., Hollowell, T., Berry, P., Kelloff, C., Alexander, S.N., 2007. Checklist of the Plants of the Guiana Shield (Venezuela: Amazonas, Bolivar, Delta Amacuro; Guyana, Surinam, French Guiana). Smithsonian Institution, Washington. http://citeseerx.ist.psu.edu/viewdoc/download?doi=10.1.1.454.3269andrep=rep1andty pe=pdf. (accessed 11.05.16).

Gehrig-Downie, C., Obregón, A., Bendix, J., Gradstein, S.R., 2011. Epiphyte biomass and canopy microclimate in the tropical lowland cloud forest of French Guiana. Biotropica 43, 591-596.

Gehrig-Downie, C., Obregón, A., Bendix, J., Gradstein, S.R., 2013. Diversity and vertical distribution of epiphytic liverworts in lowland rain forest and lowland cloud forest of French Guiana. J. Bryol. 35, 243-254.

Gond, V., Freycon, V., Molino, J.F., Brunaux, O., Ingrassia, F., Joubert, P., Pekel, J.F., Prévost, M.F., Thierron, V., Trombe, P.J., Sabatier, D., 2011. Broad-scale spatial 

pattern of forest landscape types in the Guiana Shield. Int. J. Appl. Earth Obs. Geoinf. 13, 357-367.

de Granville, J.J., 1978. Recherches sur la Flore et la Végétation Guyanaise. PhD thesis, Université des Sciences et Techniques de Montpellier, Montpellier.

de Granville, J.J., 1982. Rain forest and xeric flora refuges in French Guiana, in Prance, G.T. (Ed.), Biological Diversification in the Tropics. Columbia University Press, New York, pp. 159-181.

de Granville, J.J., 1992. Un cas de distribution particulier: les espèces forestières périamazoniennes. C. R. Soc. Biogéogr. 68, 1-33.

Grenand, P., Moretti,C., Jacquemin, H., Prévost, M.F., 2004. Pharmacopées Traditionnelles en Guyane: Créoles, Wayapi, Palikur. Institut de Recherche pour le Développement, Paris.

Gröger, A., Barthlott, W., 1996. Biogeography and diversity of the inselberg (Laja) vegetation of southern Venezuela. Biodivers. Lett. 3, 165-179.

Guitet, S., Comu, J.F., Brunaux, O., Betbeder, J., Carozza, J.M., Richard-Hansen, C., 2013. Landform and landscape mapping, French Guiana (South America). J. Maps 9, 325335.

Guitet, S., Pélissier, R., Brunaux, O., Jaouen, G., Sabatier, D., 2015. Geomorphological landscape features explain floristic patterns in French Guiana rainforest. Biodivers. Conserv. 24, 1215-1237.

Héritier, P., 2011. Le Climat Guyanais: Atlas Climatique de la Guyane Française. MétéoFrance, Cayenne.

Hill, M.O., Smith, A.J.E., 1976. Principal component analysis of taxonomic data with multistate discrete characters. Taxon 25, 249-255. 
Hooghiemstra, H., van der Hammen, T., 1998. Neogene and Quaternary development of the neotropical rain forest: the forest refugia hypothesis, and a literature overview. Earth Sci. Rev. 44, 147-183.

Howe, H.F., Smallwood, J., 1982. Ecology of seed dispersal. Ann. Rev. Ecol. Syst. 13, 201228.

Hurault, J., 1973. Les inselbergs rocheux des régions tropicales humides, témoins de paléoclimats. CR Soc. Biogéogr. 439, 49-54.

Hurault, J., 1989. Français et Indiens en Guyane: 1604-1972. Guyane Presse Diffusion, Cayenne.

Keeley, J.E., Fotheringham, C.J., Baer-Keeley, M., 2006. Demographic patterns of postfire regeneration in Mediterranean-climate shrublands of California. Ecol. Monogr. 76, 235-255.

Kelloff, C.L., Funk, V.A., 2004. Phytogeography of the Kaieteur Falls, Potaro Plateau, Guyana: floral distributions and affinities. J. Biogeogr. 31, 501-513.

Kluge, J., Kessler, M. and Dunn, R.R., 2006. What drives elevational patterns of diversity? A test of geometric constraints, climate and species pool effects for pteridophytes on an elevational gradient in Costa Rica. Global Ecol. Biogeogr. 15, 358-371.

Kounda-Kiki, C., Ponge, J.F., Mora, P., Sarthou, C., 2008. Humus profiles and successional development in a rock savanna (Nouragues inselberg, French Guiana): a micromorphological approach infers fire as a disturbance event. Pedobiologia, 52, 8595.

Legendre, P., Galzin, R., Harmelin-Vivien, M.L., 1997. Relating behavior to habitat: solutions to the fourth-corner problem. Ecology 78, 547-562. 
607

608

609

610

611

612

613

614

615

616

617

618

619

620

621

622

623

624

625

626

627

628

629

630

631

López, R.P., Squeo, F.A., Armas, C., Kelt, D.A., Gutiérrez, J.R., 2016. Enhanced facilitation at the extreme end of the aridity gradient in the Atacama Desert: a community-level approach. Ecology 97, 1593-1604.

Lorts, C.M., Briggeman, T., Sang, T., 2008. Evolution of fruit types and seed dispersal: a phylogenetic and ecological snapshot. J. Syst. Evol. 46, 396-404.

Lüttge, U., 2007. Clusia: a Woody Neotropical Genus of Remarkable Plasticity and Diversity. Springer, Berlin.

Mayle, F.E., Power, M.J., 2008. Impact of a drier Early-Mid-Holocene climate upon Amazonian forests. Phil. Trans. R. Soc. B 363, 1829-1838.

Monneveux, P., Belhassen, E., 1996. The diversity of drought adaptation in the wide. Plant Growth Regul. 20, 85-92.

Oldenburger, F.H.F., Norde, R., Riezebos, H.T., 1973. Ecological Investigations on the Vegetation of the Sipaliwini Savanna Area in Southern Surinam. University of Utrecht, Laboratory of Physical Geography, Internal Report. http://www.sipaliwinisavanna.com/docs/ecological_investigations_vegetation_sipaliwi ni_savanna.pdf. (accessed 11.05.16).

Parmentier, I., Hardy, O.J., 2009. The impact of ecological differentiation and dispersal limitation on species turnover and phylogenetic structure of inselberg's plant communities. Ecography 32, 613-622.

Parmentier, I., Stévart, T., Hardy, O.J., 2005. The inselberg flora of Atlantic Central Africa. I. Determinants of species assemblages. J. Biogeogr. 32, 685-696.

Pennington, R.T., Prado, D.E, Pendry, C.A. 2000. Neotropical seasonally dry forests and Pleistocene vegetation changes. J. Biogeogr. 27, 261-273.

Pennington, R. T., Lavin, M., Prado, D.E, Pendry, C.A., Pell, S.K, Butterworth, C.A., 2004. Historical climate change and speciation: Neotropical seasonally dry forest plants 

show patterns of both Tertiary and Quaternary diversification. Phil. Trans. R. Soc. B 359, 515-538.

Pinter, N., Fiedel, S., Keely, J. E., 2011. Fire and vegetation shifts in the Americas at the vanguard of Paleoindian migration. Quaternary Sci. Rev. 30, 269-272.

Piperno, D.R., 2011. The origins of plant cultivation and domestication in the New World tropics. Curr. Anthropol. 52, 453-470.

Plew, M.G., 2005. The archaeology of Iwakrama and North Rupununi. Proc. Acad. Nat. Sci. Philadelphia 154, 7-28.

Porembski, S., Barthlott, W., 2000. Inselbergs: Biotic Diversity of Isolated Rock Outcrops in Tropical and Temperate Regions. Springer, Berlin.

Porembski, S., Becker, U., Seine, R., 2000. Islands on islands: habitats on inselbergs, in Porembski, S., Barthlott, W. (Eds.), Inselbergs: Biotic Diversity of Isolated Rock Outcrops in Tropical and Temperate Regions. Springer, Berlin, pp. 49-67.

Porembski, S., Martinelli, G., Ohlemüller, R., Barthlott, W., 1998. Diversity and ecology of saxicolous vegetation mats on inselbergs in the Brazilian Atlantic rainforest. Divers. Distrib. 4, 107-119.

Prance, G.T., 1996. Islands in Amazonia. Phil. Trans. Roy. Soc. London B 351, 823-833.

R Core Team (2016) R: a Language and Environment for Statistical Computing. R foundation for Statistical Computing, Vienna.

Ramsay P.M., Oxley, E.R.B., 1997. The growth form composition of plant communities in the Ecuadorian paramos. Plant Ecol. 131, 173-192.

Roosmalen, M., 1985. Fruits of the Guianan Flora. Institute of Systematic Botany, Utrecht. Rull, V., 2005. Biotic diversification in the Guayana Highlands: a proposal. J. Biogeogr. 32, 921-927. 
656

657

658

659

660

661

662

663

664

665

666

667

668

669

670

671

672

673

674

675

676

677

678

679

680

Sabatier, D., Prévost, M.F., 1990. Quelques données sur la composition floristique et la diversité des peuplements forestiers de Guyane Française. Bois For. Trop. 219, 31-55.

Sarthou, C., 1992. Dynamique de la Végétation Pionnière sur un Inselberg en Guyane Française. PhD thesis, Université Pierre-et-Marie-Curie, Paris.

Sarthou, C., Grimaldi, C., 1992. Mécanisme de colonisation par la végétation d’un inselberg granitique en Guyane française. Rev. Écol. Terre Vie 47, 329-349.

Sarthou, C., Villiers, J.F., 1998. Epilithic plant communities on inselbergs in French Guiana. J. Veg. Sci. 9, 847-860.

Sarthou, C., Thérézien, Y., Couté, A., 1995. Cyanophycées de l’inselberg des Nouragues. Nova Hedwigia 61, 85-109.

Sarthou, C., Villiers, J.F., Ponge, J.F., 2003. Shrub vegetation on tropical granitic inselbergs in French Guiana. J. Veg. Sci. 14, 645-652.

Sarthou, C., Kounda-Kiki, C., Vaçulik, A., Mora, P., Ponge, J.F., 2009 Successional patterns on tropical inselbergs: a case study on the Nouragues inselberg (French Guiana). Flora 204, 396-407.

Schnitzer, S.A., 2005. A mechanistic explanation for global patterns of liana abundance and distribution. Am. Nat. 166, 262- 276.

Silvera, K., Santiago, L.S., Cushman, J.C., Winter, K., 2009. Crassulacean acid metabolism and epiphytism linked to adaptive radiations in the Orchidaceae. Plant Physiol. 149, 1838-1847.

Silvera, K., Santiago, L.S., Cushman, J.C., Winter, K., 2010 The incidence of crassulacean acid metabolism in Orchidaceae derived from carbon isotope ratios: a checklist of the flora of Panama and Costa Rica. Bot. J. Linn. Soc. 163, 194-222.

Spjut, R.W., 1994. A Systematic Treatment of Fruit Types. New York Botanical Garden, New York. 
681

682

683

684

685

686

687

688

689

690

691

692

693

694

695

696

697

698

699

700

701

702

703

704

705

706

Steyermark, J.A., Berry, P.E., Yatskievych, K., Holst, B.K., 1995-2005. Flora of the Venezuelan Guayana, Volumes I-IX. Timber Press, Portland and Missouri Botanical Garden Press, St. Louis.

Stone, L., Roberts, A., 1990. The checkerboard score and species distribution. Oecologia 85, 74-79.

Tardy, C., 1998. Paléoincendies Naturels, Feux Anthropiques et Environnements Forestiers de Guyane Française du Tardiglaciaire à l’Holocène Récent: Approches Chronologiques et Anthracologiques. PhD thesis, Université Montpellier 2, Montpellier.

Teixeira, W., Tassinari, C.C.G, Cordani, U.G., Kawashita, K., 1989. A review of the geochronology of the Amazonian craton: tectonic implications. Precambrian Res. 42, 213-227.

Ter Steege, H., Sabatier, D., Castellanos, H., Van Andel, T., Duivenvoorden, J., Adalardo de Oliveira, A., Ek, R., Lilwah, R., Maas, P., Mori, S., 2000. An analysis of the floristic composition and diversity of Amazonian forests including those of the Guiana Shield. J. Tropic. Ecol. 16, 801-828.

Vaçulik, A., Kounda-Kiki, C., Sarthou, C., Ponge, J.F., 2004. Soil invertebrate activity in biological crusts on tropical inselbergs. Eur. J. Soil Sci. 55, 539-549.

Valbuena, L., Trabaud, L., 2001. Contribution of the soil seed bank to post-fire recovery of a heathland. Plant Ecol. 152, 175-183.

van der Pijl, L., 1982. Principles of Dispersal in Higher Plants. Springer, New York.

van Donselaar, J., 1968. Phytogeographic notes on the savanna flora of Southern Surinam (South America). Acta Bot. Neerland. 17, 363-404.

Willis, K. J., Whittaker, R. J. 2000. The refugial debate. Science 287, 1406-1407.

Vuilleumier, F., 1970. Insular biogeography in continental regions. I. The northern Andes of South America. Am. Nat. 104, 373-388.

Wiens, J.A., 1989. Spatial scaling in ecology. Funct. Ecol. 3, 385-397. 
707 Table 1. Traits and biogeographic affinities of plant species used in RLQ and fourth-corner tests.

708 Numbers between brackets are the scores used for the ordinal variable describing the degree of Guiana

709 Shield endemism

\begin{tabular}{llll}
\hline Taxonomic unit & Fern & Fruit type & Fleshy fruit \\
& Magnoliid & & Dry dehiscent fruit \\
& Monocot & & Dry indehiscent fruit \\
& Sudicot & & Sporangium \\
Growth form & Erect herb & Seed dispersal syndrome & Anemochory \\
& Rosette & & Zoochory \\
& Cespitose & & Autochory \\
& Suffrutex & & Hydrochory \\
& Upright shrub & \multirow{2}{*}{ Carbon fixation pathway } & C3 \\
& Trailing shrub & & C4 \\
& Parasitic shrub & & CAM \\
& Small tree & Biogeographic affinity & Pantropical or cosmopolite (1) \\
& Climber & & Endemic of the Neotropics (2) \\
& Succulent & & Endemic of the Guiana Shield (3) \\
\hline
\end{tabular}

710 
Table 2. Number of species in dominant plant families over all inselbergs and in each of the two inselberg groups

\begin{tabular}{|c|c|c|c|}
\hline & All inselbergs & $\begin{array}{l}\text { Northern/Mitaraka/Saint } \\
\text { Marcel group }\end{array}$ & Peneplain group \\
\hline & 74 families & 69 families & 55 families \\
\hline & 318 species & 265 species & 149 species \\
\hline Bromeliaceae & 15 & 12 & 6 \\
\hline Clusiaceae & 10 & 11 & 4 \\
\hline Сyperaceae & 19 & 18 & 10 \\
\hline Euphorbiaceae & 10 & 9 & 5 \\
\hline Fabaceae & 14 & 11 & 8 \\
\hline Melastomataceae & 20 & 17 & 11 \\
\hline Myrtaceae & 15 & 13 & 2 \\
\hline Orchidaceae & 20 & 19 & 6 \\
\hline Poaceae & 21 & 16 & 14 \\
\hline Rubiaceae & 18 & 15 & 7 \\
\hline
\end{tabular}

712 
Table 3. Decomposition of the total variance of species and species traits according to environmental and spatial factors, using simple and partial RDA (Borcard et al., 1992)

\begin{tabular}{lll}
\hline & Species & Traits \\
\hline Pure environment & $50.4 \%$ & $45.4 \%$ \\
Pure spatial & $33.3 \%$ & $24.5 \%$ \\
Spatially-structured environment & $10.0 \%$ & $19.9 \%$ \\
Total explained variation & $93.7 \%$ & $89.8 \%$ \\
Unexplained variation & $6.3 \%$ & $10.2 \%$ \\
\hline
\end{tabular}


Table 4. Checkerboard scores (C-scores) for co-occurrence of plant species on Guianan inselbergs. Numbers of inselbergs for all inselbergs and for Wanapi and Haut Marouini archipelagos are indicated between parentheses

\begin{tabular}{lllllll}
\hline & $\begin{array}{l}\text { Observed } \\
\text { index }\end{array}$ & $\begin{array}{l}\text { Simulated } \\
\text { index }\end{array}$ & $\begin{array}{l}\mathrm{P}(\text { obs }< \\
\text { sim) }\end{array}$ & $\begin{array}{l}\text { P (obs } \\
\text { > sim) }\end{array}$ & $\begin{array}{l}\text { Standardized } \\
\text { effect size }\end{array}$ & $\begin{array}{l}\text { Null } \\
\text { hypothesis }\end{array}$ \\
\hline All inselbergs (22) & 7.71 & 7.11 & 1 & 0 & 31.12 & Rejected \\
Wanapi (5) & 0.040 & 0 & 0.54 & 0.47 & -0.057 & Accepted \\
Haut Marouini (6) & 0.097 & 0.096 & 0.85 & 0.15 & 0.94 & Accepted \\
\hline
\end{tabular}




\section{Figure captions}

Fig. 1. Map of French Guiana, showing the 22 studied inselbergs (red triangles; each letter designates an isolated inselberg), among the whole set of inselbergs (black dots), the water system and rainfall isohyets. Inserts at the top of the figure indicate the position of French Guiana within South America (left) and within the Guiana Shield (right), with country limits. Country names are indicated by their capitalized initial: B: Brazil; C: Colombia; FG: French Guiana; G: Guyana; S: Suriname; V: Venezuela. Savannalike vegetation zones are colored. 1: Roraima; 2: Rupununi; 3: Sipaliwini; 4: Coastal savannas; 5: Llanos.

Fig. 2. RLQ multivariate analysis. Projection of sites (inselbergs) in the plane of the first two main components RLQ1 and RLQ2. Insert: distribution of eigenvalues in order of decreasing importance. WAN A to WAN E = Wanapi archipelago; HMA to HMG = Haut Marouini archipelago; ARA = Arawa; DAC = Roche Dachine; MIT = Mitaraka; SMA = Mont saint Marcel; NOU = Nouragues; VIR = Virginie; CHAU = Mont Chauve; TRI A and TRI B = Trinité archipelago; BAK A and BAK B = Monts Bakra archipelago. See Fig. 1 for their localization.

Fig. 3. RLQ multivariate analysis. Projection of plant species in the plane of the first two main components RLQ1 and RLQ2. The number of plant species is much higher than the number of dots indicated on the bi-plot, because many of them are superposed. Some important species have been stamped (for abbreviations see Appendix B).

Fig. 4. RLQ multivariate analysis and fourth-corner tests. Projection of species traits in the plane of the first two main components RLQ1 and RLQ2. Variables with significant relationships with RLQ1 (fourth-corner tests) are indicated with arrows. Each trait name is centered on the corresponding point. 
744 Fig. 5. RLQ multivariate analysis and fourth-corner tests. Projection of environmental

745

746

747

748 variables in the plane of the first two main components RLQ1 and RLQ2. Variables with significant relationships with RLQ1 (fourth-corner tests) are indicated with arrows. Each trait name is centered on the corresponding point.

Fig. 6. Relationship between floristic dissimilarity (Jaccard index for species, Spearman rank dissimilarity index for species traits) and geographical distance for inselbergs located within archipelagos (less than $7 \mathrm{~km}$ distance). $\mathrm{y}=$ floristic dissimilarity; $\mathrm{x}=$ geographic distance $(\mathrm{km}) ; \mathrm{r}_{\mathrm{M}}=$ Mantel coefficient of correlation; $*=\mathrm{P}<0.05$; NS = not significant. 


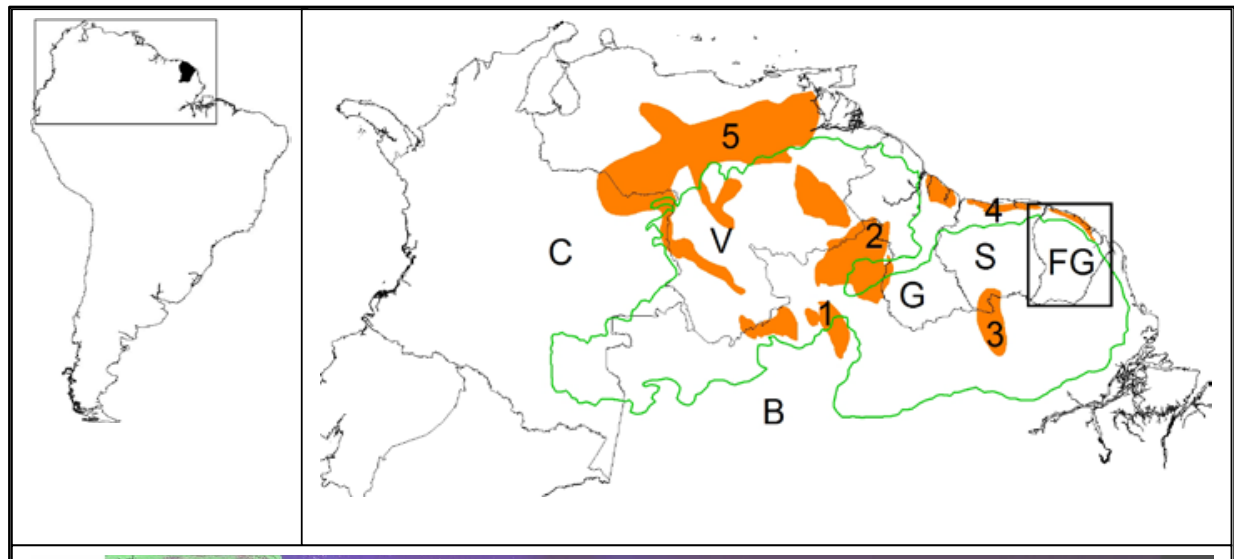

760

761

762

763

764

765

766

767

768

769

770

771

772

773

774

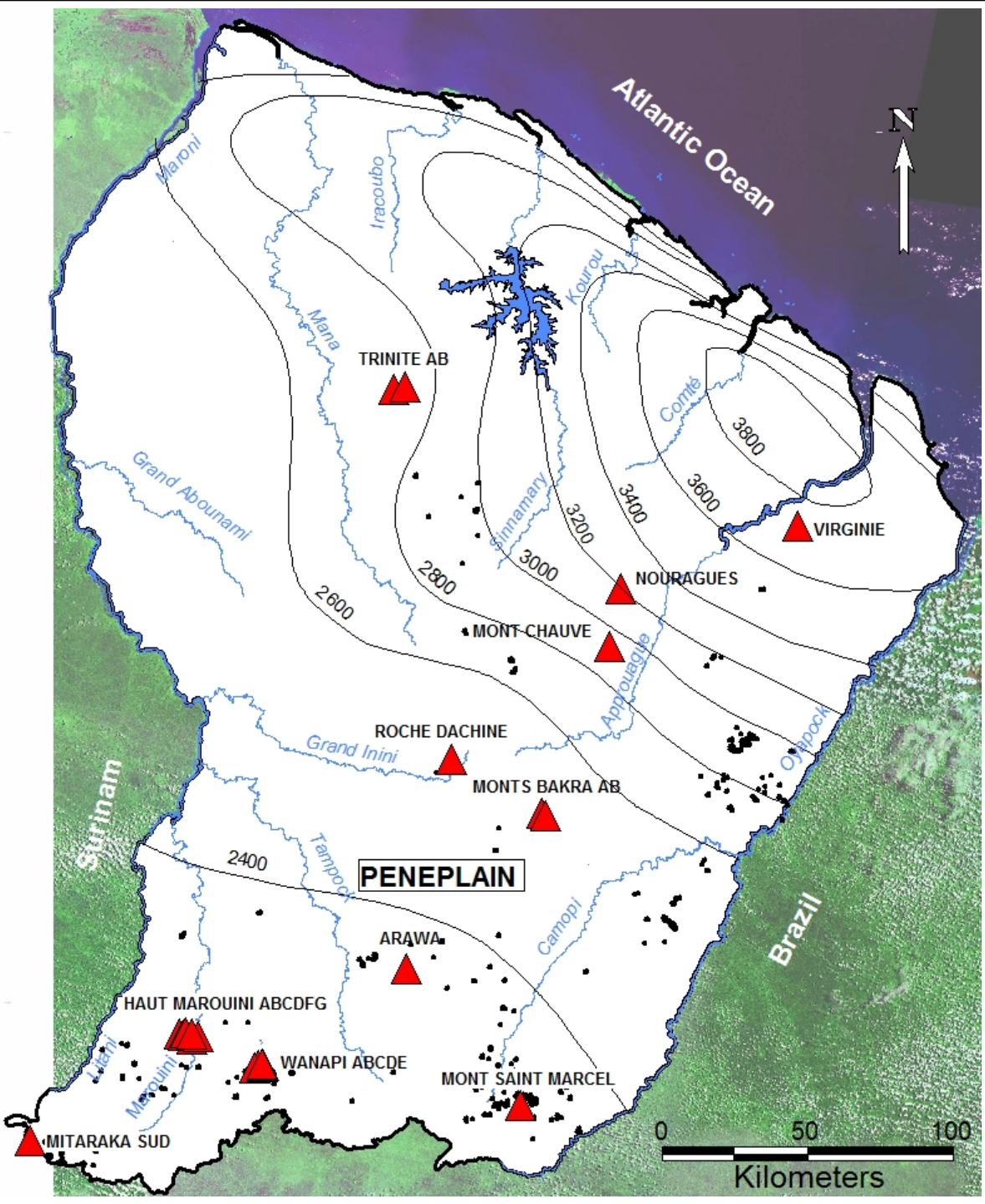

775

$776 \quad$ Fig. 1

777 




$779 \quad$ Fig. 2 


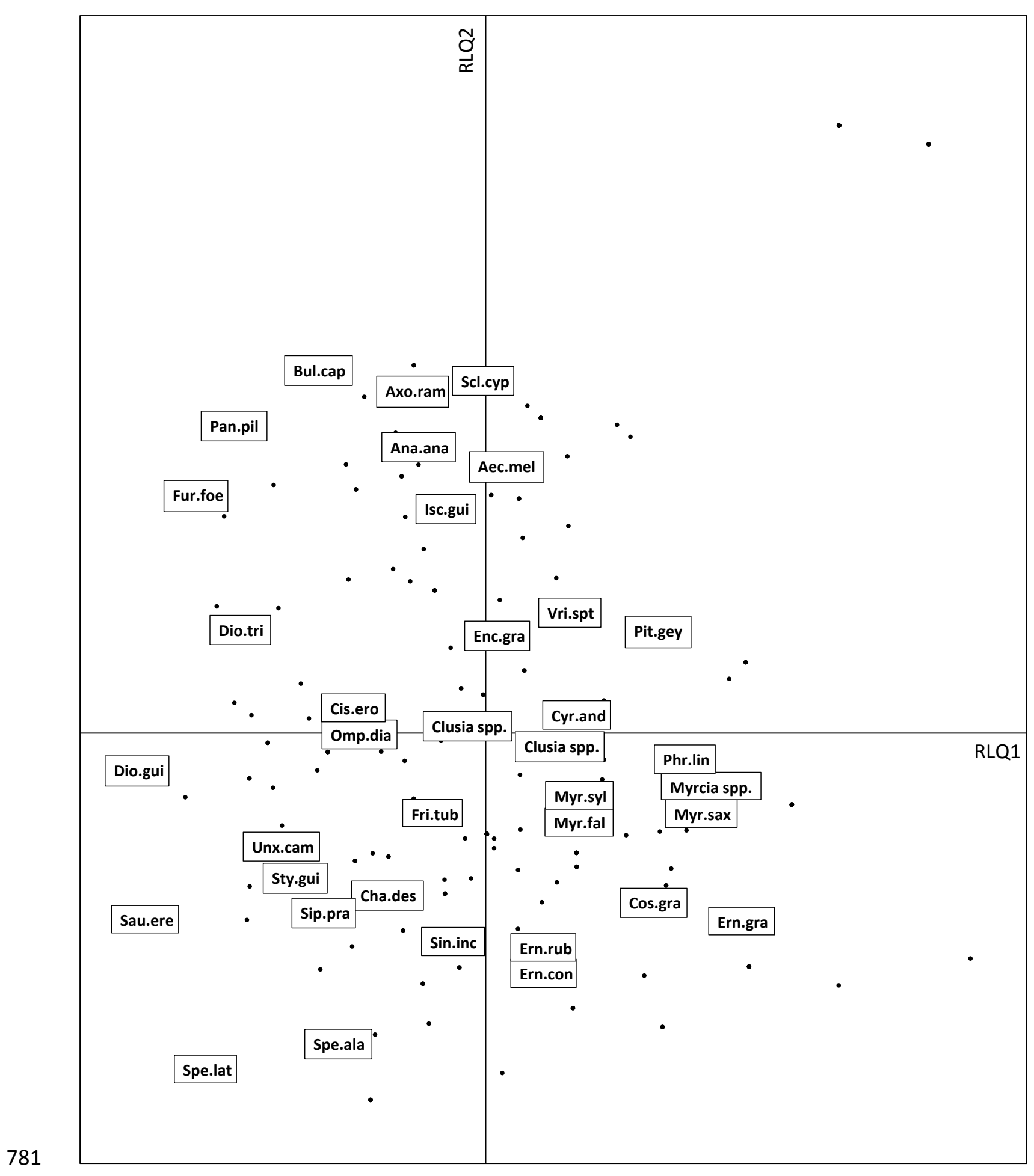

Fig. 3 


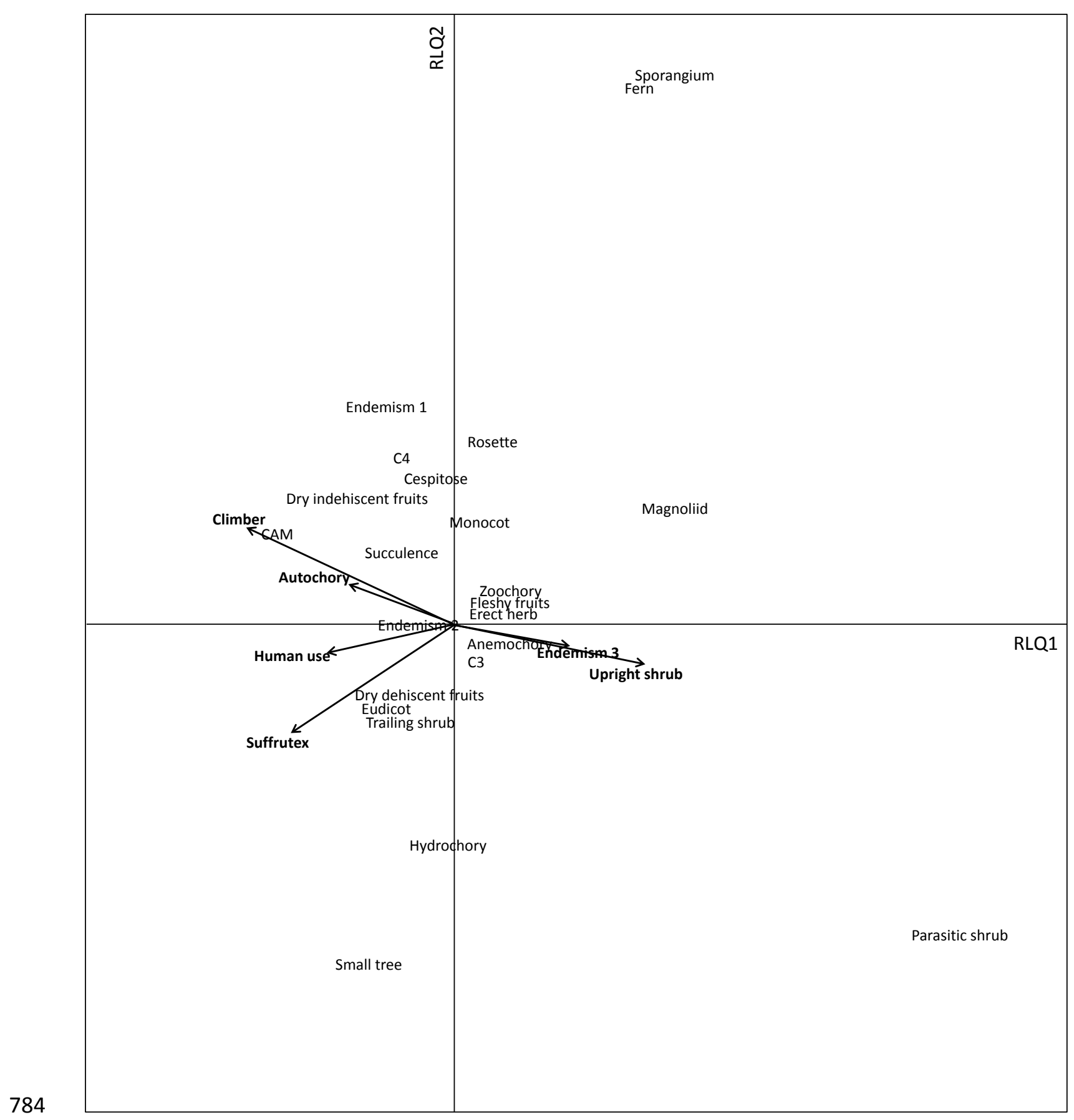

$785 \quad$ Fig. 4 


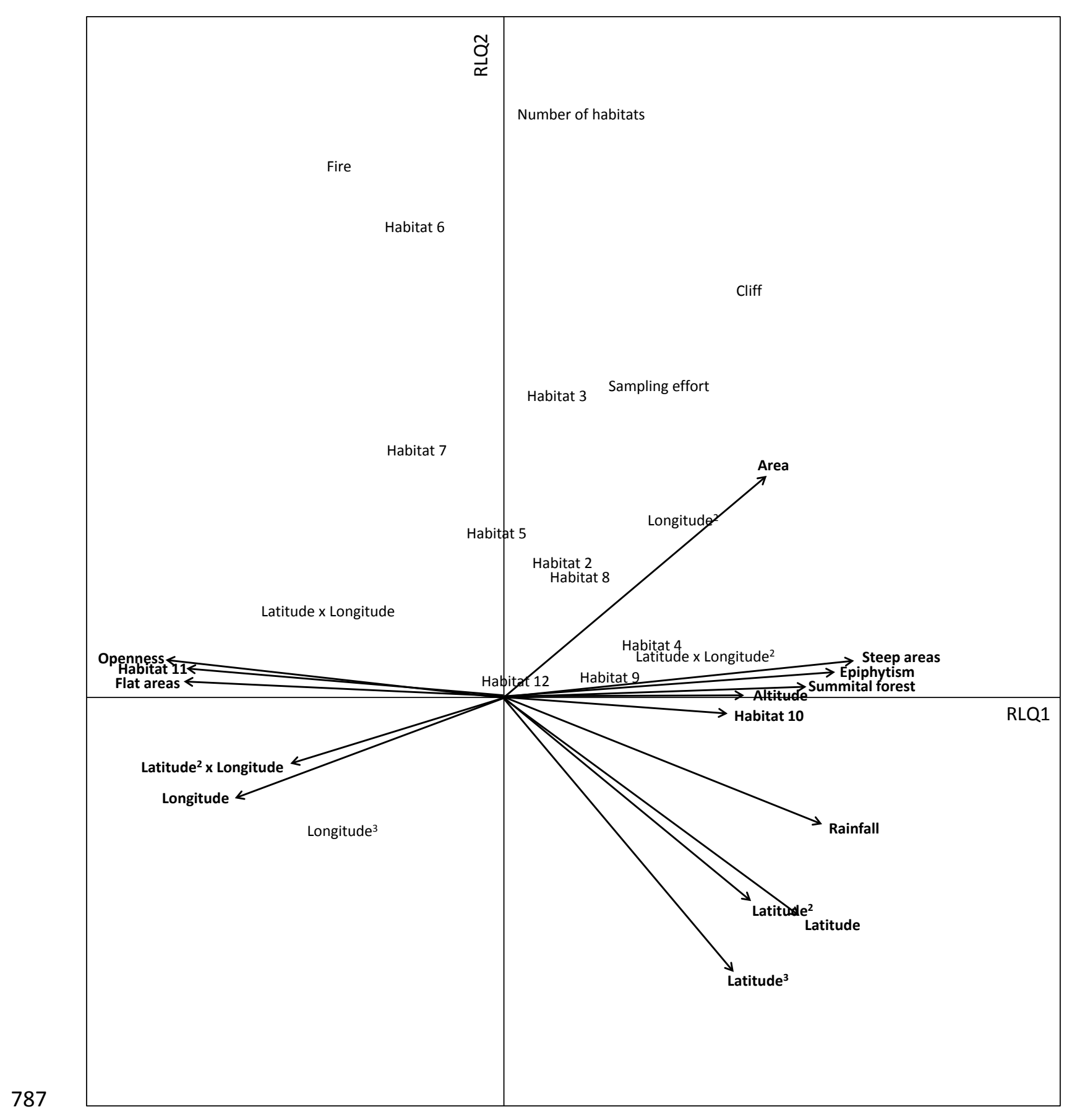

$788 \quad$ Fig. 5 


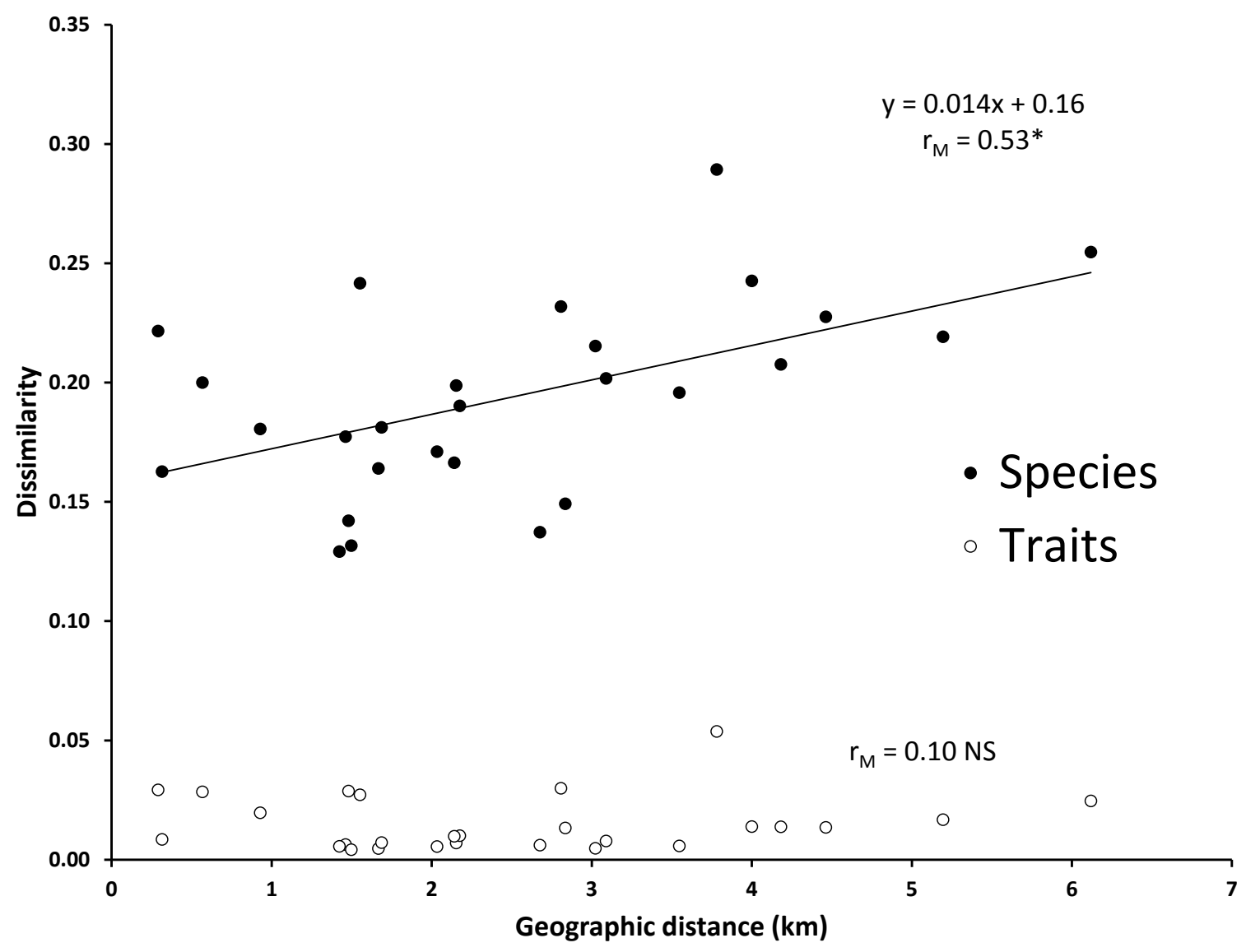

791 Fig. 6

792 